\title{
Identifikasi Bakteri dengan Pewarnaan Gram pada Penderita Infeksi Mata Luar di Rumah Sakit Mata Kota Manado
}

\author{
${ }^{1}$ Trijeri Bulele \\ ${ }^{2}$ Fredine E. S. Rares \\ ${ }^{2}$ John Porotu'o
}
${ }^{1}$ Program Studi Pendidikan Dokter Fakultas Kedokteran Universitas Sam Ratulangi Manado
${ }^{2}$ Bagian Mikrobiologi Fakultas Kedokteran Universitas Sam Ratulangi
Email: trijerrybulele@gmail.com

\begin{abstract}
Bacteria are the main cause of external ocular infection worldwide. Therefore, it is necessary to improve the treatment according to the cause of the infection in order to prevent the emergence of antibiotic-resistant bacteria. This study was aimed to identify the bacteria by using the Gram staining method in patients with external ocular infections. This was a descriptive study with a cross sectional design using bacterial culture of purulent secretion obtained from conjunctival and palpebral swabs in patients with external ocular infections at Manado Eye Hospital Manado. Based on the types of external ocular infections, conjunctivitis was the leading cause (50\%), followed by keratitis (30\%), blepharitis (13.3\%), and keratoconjunctivitis $(6.7 \%)$. Females were more frequeny than males $(63.3 \%$ vs $36.7 \%)$. The youngest age in this study was 9 years and the oldest was 81 years, meanwhile, the most common age group was adults $>40$ years. The most common type of occupation was housewives. The results of bacterial culture were as follows: 19 samples showed no growth; 6 samples $(54.5 \%)$ of Gram-positive bacteria in the form of staphylococcus, coccus, diplococcus; 3 samples (27.3\%) of Gram-negative bacteria in the form of bacillus; and 2 samples (18.2\%) of mixed Gram positive and negative bacteria in the form of bacillus and coccus. Conclusion: Gram-positive bacterium in the form of coccus is the most common cause of external ocular infection.
\end{abstract}

Keywords: external ocular infection, bacteria, Gram staining

\begin{abstract}
Abstrak: Bakteri ialah penyebab utama infeksi mata luar di seluruh dunia. Pengobatan yang sesuai dengan penyebab infeksi dapat mencegah munculnya bakteri yang resistan terhadap antibiotik. Penelitian ini bertujuan untuk mengidentifikasi bakteri dengan menggunakan metode pewarnaan Gram pada penderita infeksi mata luar. Jenis penelitian ialah deskriptif dengan desain potong lintang menggunakan kultur bakteri hasil swab sekret purulen dari konjungtiva dan palpebra pada penderita infeksi mata luar di Rumah Sakit Mata Kota Manado. Hasil penelitian mendapatkan bahwa jenis infeksi mata luar terbanyak ialah konjungtivitis (50\%), diikuti oleh keratitis (30\%), blefaritis (13,3\%), dan keratokonjungtivitis $(6,7 \%)$. Perempuan lebih banyak $(63,3 \%)$ menderita infeksi mata luar dibandingkan laki-laki $(36,7 \%)$. Usia termuda ialah 9 tahun dan tertua 81 tahun. Kelompok usia terbanyak ialah dewasa $>40$ tahun. Jenis pekerjaan ibu rumah tangga yang terbanyak dibandingkan dengan pekerjaan lainnya. Hasil proses kultur mendapatkan 19 sampel tidak menunjukan adanya pertumbuhan, 6 sampel (54,5\%) bakteri Gram positif dengan bentuk staphylococcus, coccus, diplococcus, 3 sampel (27,3\%) bakteri Gram negatif dengan bentuk bacillus, dan 2 sampel (18.2\%) campuran bakteri Gram positif dan negatif dengan bentuk bacillus dan coccus. Simpulan: Bakteri Gram positif berbentuk coccus yang paling sering menjadi penyebab infeksi mata luar.
\end{abstract}

Kata kunci: infeksi mata luar, bakteri, pewarnaan Gram 
Salah satu panca indra yang sangat penting dalam kehidupan manusia ialah mata. Jika kesehatan mata tidak dijaga dengan baik, maka akan terjadi gangguan berupa infeksi pada mata yang dapat mengganggu aktivitas sehari-hari. ${ }^{1}$

Infeksi pada mata dapat disebabkan oleh faktor endogen seperti flora residen yang menjadi patogen, dan faktor eksogen seperti masuknya mikroorganisme dari lingkungan luar. ${ }^{2}$ Mikroorganisme penyebab infeksi pada mata antara lain bakteri, jamur, virus, dan parasit patogen. ${ }^{3}$ Bakteri merupakan penyebab utama infeksi pada mata dan kemungkinan bisa menyebabkan kebutaan. ${ }^{4}$ Infeksi mata luar termasuk blefaritis, hordeolum, dakriosistitis, kanalikulitis, konjungtivitis, keratitis, skleritis, selulitis orbital dan periorbital, blepharokonjungtivitis, keratokonjungtivitis, dan lain-lain. ${ }^{5-7}$ Beberapa faktor yang berhubungan dengan Infeksi pada mata seperti penggunaan lensa kontak, trauma, pembedahan, usia, mata kering, obstruksi, dan riwayat infeksi mata sebelumnya. ${ }^{8,9}$

Menurut data World Health Organization (WHO) pada tahun 2018 jumlah orang yang mengalami gangguan penglihatan di seluruh dunia yaitu 1,3 milyar, 188,5 juta orang memiliki gangguan penglihatan ringan, 217 juta memiliki gangguan penglihatan sedang sampai berat, dan 36 juta orang mengalami kebutaan. Laporan tersebut juga menunjukkan bahwa $80 \%$ dari semua gangguan penglihatan dapat dihindari. ${ }^{10}$ Di Indonesia sendiri menurut data Riset Kesehatan Dasar (Riskesdas) tahun 2013 terdapat 924.780 orang mengalami gangguan penglihatan. ${ }^{11}$ Berdasarkan hasil survei pendahuluan yang dilakukan di Balai Kesehatan Mata Masyarakat (BKMM) Kota Manado pada tahun 2017 didapatkan 1.802 kasus baru dan 2.673 kasus lama dengan total 4.475 pasien mengalami infeksi mata di antara 40.606 pasien yang datang untuk mendapatkan pelayanan kesehatan mata di BKMM Kota Manado. ${ }^{12}$

Pada penelitian yang dilakukan Wang et $\mathrm{al}^{13}$ di Cina periode Januari 2010 sampai Desember 2013 didapatkan 610 pasien infeksi mata luar dengan penyebab bakteri yang terdiri dari 478 kasus $(78,36 \%)$ Gram positif dan 132 kasus $(21,64 \%)$ Gram negatif. Penelitian yang dilakukan Shiferaw et $\mathrm{al}^{14}$ di Etiopia melaporkan bahwa dari 160 total kasus infeksi mata luar terdapat 95 (59,4\%) kasus dengan penyebab bakteri. Penyebab bakteri terdiri dari Gram positif sebanyak $89(93,7 \%)$ dan Gram negatif sebanyak $6(6,3 \%)$. Sebuah studi potong lintang yang dilakukan dari Juli 2016 sampai Desember 2016 di Rumah Sakit Mohan Kumaramangalam, India Selatan melibatkan 110 orang dicurigai infeksi mata luar dan didapatkan sebanyak 54 subyek (49\%) dengan pertumbuhan bakteri. Bakteri yang tumbuh yaitu Gram positif sebanyak 36 subyek (67\%) dan Gram negatif sebanyak 15 subyek $(28 \%)$ serta 3 subyek $(5 \%)$ dengan infeksi jamur. ${ }^{15}$

Dari beberapa penelitian di atas dapat disimpulkan bahwa bakteri merupakan penyebab utama infeksi mata luar di seluruh dunia. Jika tidak ditangani dengan cepat, maka infeksi tersebut dapat merusak struktur mata sehingga mengakibatkan gangguan penglihatan dengan kemungkinan terjadinya kebutaan. ${ }^{16}$

Berdasarkan latar belakang diatas perlu dilakukan penelitian tentang identifikasi bakteri dengan pewarnaan Gram pada penderita infeksi mata luar khusunya di Rumah Sakit Mata Kota Manado untuk mengetahui bakteri penyebab infeksi mata agar mendapatkan pengobatan yang sesuai dengan penyebab infeksi dan mencegah munculnya bakteri yang resistan antibiotik.

\section{METODE PENELITIAN}

Penelitian ini menggunakan metode deskriptif dengan desain potong lintang melalui kultur bakteri hasil swab sekret purulen dari konjungtiva dan palpebra pada penderita infeksi mata luar di Rumah Sakit Mata Kota Manado periode AgustusDesember 2018. Pengambilan sampel dilakukan pada bulan November-Desember 2018 di Rumah Sakit Mata Kota Manado Kota Manado dan Pengelolaan sampel dilakukan di Laboratorium Mikrobiologi Fakultas Kedokteran Unsrat. Pengambilan sampel menggunakan media transpor Cary- 
Blair. Swab steril disapukan secara lembut di daerah konjungtiva dari medial ke lateral mata pasien yang terinfeksi setelah diberi 1-2 tetes pantocain $0,5 \%$. Untuk palpebra dilakukan pengambilan secara langsung di daerah silia. Sampel di masukkan ke dalam cool box dan dibawa ke Laboratorium Mikrobiologi Fakultas Kedokteran Unsrat. Isolasi bakteri menggunakan media Mac Conkey dan nutrient agar dengan cara diinokulasikan pada kedua media tersebut, kemudian diinkubasikan pada suhu $37^{\circ} \mathrm{C}$ selama 24 jam. Setelah tumbuh koloni, dilakukan identifikasi bakteri dengan menggunakan metode pewarnaan Gram.

\section{HASIL PENELITIAN}

Tabel 1 menunjukkan bahwa distribusi subyek berdasarkan jenis infeksi mata luar didapatkan konjungtivitis 15 orang (50\%), keratitis 9 orang $(30 \%)$, blefaritis 4 orang $(13,3 \%)$, dan keratokonjungtivitis 2 orang $(6,7 \%)$.

Tabel 1. Distribusi subyek berdasarkan jenis infeksi mata luar

\begin{tabular}{lcc}
\hline $\begin{array}{c}\text { Jenis infeksi } \\
\text { mata luar }\end{array}$ & $\begin{array}{c}\text { Jumlah } \\
\text { penderita }\end{array}$ & $\begin{array}{c}\text { Persentase } \\
(\%)\end{array}$ \\
\hline Konjungtivitis & 15 & 50 \\
Keratitis & 9 & 30 \\
Blefaritis & 4 & 13,3 \\
Kerato- & 2 & 6,7 \\
konjungtivitis & 30 & 100 \\
\hline Total & 30 \\
\hline
\end{tabular}

Tabel 2 menunjukkan distribusi sampel berdasarkan jenis kelamin dan didapatkan hasil 11 orang berjenis kelamin laki-laki $(36,7 \%)$, dan 19 orang berjenis kelamin perempuan $(63,3 \%)$.

Tabel 2. Distribusi subyek berdasarkan jenis kelamin

\begin{tabular}{lcc}
\hline Jenis kelamin & $\begin{array}{c}\text { Jumlah } \\
\text { penderita }\end{array}$ & $\begin{array}{c}\text { Persentase } \\
(\%)\end{array}$ \\
\hline Laki-laki & 11 & 36,7 \\
Perempuan & 19 & 63,3 \\
Total & 30 & 100 \\
\hline
\end{tabular}

Tabel 3 menunjukkan distribusi subyek menurut kelompok usia. Didapatkan hasil kelompok usia 1 bulan-10 tahun sebanyak 1 orang (3,3\%); usia 11-20 tahun, 21-30 tahun, dan 31-40 tahun masing-masing sebanyak 3 orang (10\%); usia 41-50 tahun sebanyak 9 orang (30\%); usia 51-60 tahun sebanyak 2 orang (6,7\%); dan usia >60 tahun sebanyak 9 orang (30\%).

Tabel 3. Distribusi subyek berdasarkan kelompok usia

\begin{tabular}{lcc}
\hline Kelompok usia & $\begin{array}{c}\text { Jumlah } \\
\text { penderita }\end{array}$ & $\begin{array}{c}\text { Persentase } \\
(\mathbf{\%})\end{array}$ \\
\hline 1 bulan - 10 tahun & 1 & 3,3 \\
11-20 tahun & 3 & 10 \\
21-30 tahun & 3 & 10 \\
31-40 tahun & 3 & 10 \\
41-50 tahun & 9 & 30 \\
51-60 tahun & 2 & 6,7 \\
>60 tahun & 9 & 30 \\
Total & 30 & 100 \\
\hline
\end{tabular}

Tabel 4 memperlihatkan bahwa jenis pekerjaan terbanyak ialah ibu rumah tangga $(36,7 \%)$ disusul oleh swasta $(26,7 \%)$ dan pelajar $(16,6 \%)$.

Tabel 4. Distribusi subyek berdasarkan jenis pekerjaan

\begin{tabular}{lcc}
\hline Jenis pekerjaan & $\begin{array}{c}\text { Jumlah } \\
\text { penderita }\end{array}$ & $\begin{array}{c}\text { Persentase } \\
(\%)\end{array}$ \\
\hline Ibu rumah tangga & 11 & 36,7 \\
Pensiunan & 3 & 10 \\
Pelajar & 5 & 16,6 \\
Tenaga harian & 1 & 3,3 \\
lepas & 2 & 6,7 \\
Petani & 8 & 26,7 \\
Swasta & 30 & 100 \\
Total & & \\
\hline
\end{tabular}

Tabel 5 menunjukan bahwa distribusi subyek berdasarkan pertumbuhan kultur bakteri didapatkan hasil 11 sampel $(36,7 \%)$ menunjukkan adanya pertumbuhan dan 19 sampel $(63,3 \%)$ tidak menunjukkan adanya pertumbuhan. 
Tabel 5. Distribusi sampel berdasarkan pertumbuhan kultur bakteri di media Mac Conkey dan nutrient agar

\begin{tabular}{lcc}
\hline \multicolumn{1}{c}{ Hasil kultur } & $\begin{array}{c}\text { Jumlah } \\
\text { sampel }\end{array}$ & $\begin{array}{c}\text { Persentase } \\
(\mathbf{\%})\end{array}$ \\
\hline Ada pertumbuhan & 11 & 36,7 \\
Tidak ada & 19 & 63,3 \\
pertumbuhan & 30 & 100 \\
Total & \\
\hline
\end{tabular}

Tabel 6 menunjukkan distribusi sampel berdasarkan hasil identifikasi dengan pewarnaan Gram secara mikroskopik. Didapatkan hasil 6 sampel $(54,5 \%)$ bakteri Gram positif dengan morfologi staphylococcus, coccus, diplococcus, 3 sampel $(27,3 \%)$ bakteri Gram negatif dengan morfologi bacillus, dan ditemukan 2 sampel $(18,2 \%)$ campuran bakteri Gram positif dan negatif dengan morfologi bacillus dan coccus.

Tabel 6. Distribusi sampel berdasarkan hasil pewarnaan Gram

\begin{tabular}{lcc}
\hline \multicolumn{1}{c}{$\begin{array}{c}\text { Jenis } \\
\text { bakteri }\end{array}$} & Morfologi & $\begin{array}{c}\text { Jumlah } \\
(\%)\end{array}$ \\
\hline Gram & $\begin{array}{c}\text { Staphylococcus, } \\
\text { coccus, } \\
\text { Positif }\end{array}$ & $6(54,5 \%)$ \\
Gram & $\begin{array}{c}\text { diplococcus } \\
\text { Positif }\end{array}$ & $3(27,3 \%)$ \\
Bakteri & Bacillus \\
Campuran & coccus & $2(18,2 \%)$ \\
\hline
\end{tabular}

\section{BAHASAN}

Pada penelitian ini didapatkan konjungtivitis ialah jenis infeksi mata luar terbanyak (50\%), diikuti dengan keratitis $(30 \%)$, blefaritis $(13,3 \%)$, dan keratokonjungtivitis $(6,7 \%)$ (Tabel 1). Hal ini sesuai dengan penelitian yang dilakukan di Etiopia dan India yang melaporkan konjungtivitis merupakan jenis infeksi mata luar terbanyak dari semua subyek penelitian yang telah dilakukan pemeriksaan sesuai dengan prosedur dan standar diagnostik penyakit mata. ${ }^{14,15}$

Subyek penelitian berjenis kelamin perempuan $(63,3 \%)$ lebih banyak menderita infeksi mata luar dibandingkan laki-laki
$(36,7 \%)$ (Tabel 2). Terdapat banyak faktor yang dapat menyebabkan seseorang terkena infeksi mata, salah satunya ialah penggunaan lensa kontak. Perempuan biasanya lebih sering menggunakan lensa kontak untuk mempercantik diri atau mengubah penampilan agar tampil beda. Penggunaan serta penyimpanan lensa kontak yang tidak baik dan tidak bersih dapat menjadi tempat mikroorganisme berkembang biak yang dapat menyebabkan infeksi pada mata. ${ }^{17}$ Hasil penelitian ini tidak sejalan dengan penelitian sebelumnya yang dilakukan di Jimma, Etiopia yang melaporkan bahwa jenis kelamin laki-laki lebih sering menderita infeksi mata dibandingkan perempuan. Hal ini berkaitan dengan aktivitas luar ruangan yang lebih sering dilakukan oleh laki-laki. ${ }^{18}$ Prevalensi infeksi mata tidak memiliki hubungan bermakna dengan jenis kelamin. ${ }^{19}$

Distribusi subyek penelitian ini memperlihatkan usia termuda ialah 9 tahun dan tertua 81 tahun (Tabel 3). Berdasarkan kelompok usia didapatkan kelompok usia 41-50 tahun dan >60 tahun paling banyak menderita infeksi mata luar yaitu 9 orang (30\%) masing-masing dari kelompok usia tersebut. Hasil penelitian ini selaras dengan yang dilakukan di Rumah Sakit Pendidikan dan Rujukan Universitas Hawasa, Etiopia Selatan tahun 2015 yang melaporkan bahwa infeksi mata lebih banyak didapatkan pada orang dewasa dibandingkan anakanak. Prevalensi infeksi mata tidak secara bermakna terkait dengan kelompok usia. ${ }^{19}$ Terdapat faktor-faktor lain yang dapat berperan dalam hal terjadinya infeksi pada mata anak. Penelitian di Aba, Nigeria Tenggara menaytakan bahwa kerentanan pada anak terhadap infeksi mata dapat disebabkan oleh karena sistem kekebalan tubuh yang belum matang atau masih rendah. ${ }^{20}$ Pada orang dewasa hal tersebut terkait dengan lingkungan pekerjaan, misalnya pekerja pabrik yang rentan terpapar dengan benda asing pada mata yang dapat menyebabkan infeksi atau pada lanjut usia karena lemahnya sistem kekebalan tubuh akibat faktor usia. ${ }^{19}$ Pada usia lebih dari 30 tahun sekresi lakrimal mulai menurun 
mengakibatkan disfungsi kelenjar meibom dan sebaseus sehingga terjadi ketidakstabilan film air mata yang mengakibatkan penguapan berlebihan; hal ini disebut juga dengan sindroma mata kering. ${ }^{21}$ Akibat terjadi pengurangan lakrimasi ini proteksi humoral oleh air mata menurun sehingga memudahkan mikroorganisme atau benda asing masuk. Pada perempuan, sindrom ini disebabkan oleh defisiensi hormone. Pada laki-laki, prevalensi sindrom mata kering tidak sebanyak pada perempuan karena adanya hormon androgen dalam jumlah yang cukup. ${ }^{21}$

Hasil penelitian ini menunjukkan bahwa jenis pekerjaan ibu rumah tangga yang tertinggi $(36,7 \%)$, diikuti oleh swasta $(26,7 \%)$, pelajar $(16,6 \%)$, pensiunan $(10 \%)$, petani $(6,7 \%)$, dan tenaga harian lepas (3.3\%) (Tabel 4). Menurut anamnesis yang dilakukan pada subyek penelitian ini, diduga faktor terkenanya infeksi mata yaitu karena adanya riwayat penyakit sebelumnya yang membuat sistem kekebalan tubuh mereka berkurang sehingga mudah untuk terpapar dengan mikroorganisme patogen.

Pada penelitian ini didapatkan pertumbuhan kultur bakteri pada 11 sampel $(36,7 \%)$; 19 sampel $(63,3 \%)$ tidak menunjukkan adanya pertumbuhan (Tabel 5). Penyebab infeksi mata antara lain oleh karena bakteri, jamur, virus, dan parasit patogen. ${ }^{3}$ Pada sampel yang tidak menunjukkan adanya pertumbuhan, terjadinya infeksi dapat disebabkan oleh faktor penyebab lain seperti virus, jamur, atau patogen lainnya. Namun tidak menutup kemungkinan pada pasien yang menderita infeksi mata dengan penyebab bakteri anaerob yang dalam penelitian ini tidak dilakukan pemeriksaan karena hanya dilakukan pemeriksaan bakteri aerob saja.

Hasil penelitian mendapatkan 6 sampel $(54,5 \%)$ bakteri Gram positif dengan morfologi staphylococcus, coccus, diplococcus; 3 sampel $(27,3 \%)$ bakteri Gram negatif dengan morfologi bacillus, dan 2 sampel $(18,2 \%)$ bakteri campuran bakteri Gram positif dan negatif dengan morfologi bacillus dan coccus. Bakteri Gram positif lebih banyak dibandingkan dengan Gram negatif sedangkan munculnya bakteri campuran dapat disebabkan oleh karena kondisi lingkungan dan kebersihan tempat penyimpanan atau pada saat dilakukan pemeriksaan sampel. ${ }^{15}$ Dari berbagai penelitian yang dilaporkan, bakteri Gram positif yang terbanyak menyebabkan infeksi baik pada mata luar maupun dalam. ${ }^{13,16} \mathrm{Hal}$ tersebut selaras dengan hasil penelitian ini yaitu bakteri Gram positif paling banyak menyebabkan infeksi pada mata.

Pada pewarnaan Gram terdapat 2 jenis bakteri yaitu Gram positif dan Gram negatif. Tujuan dari pewarnaan Gram ini yaitu untuk mempermudah melihat bakteri secara mikroskopik, memperjelas ukuran dan bentuk bakteri, melihat struktur dalam bakteri seperti dinding sel dan vakuola, dan menghasilkan sifat-sifat fisik serta kimia khas dari bakteri dengan zat warna. Dalam pewarnaan, bakteri Gram positif berwarna ungu sedangkan bakteri Gram negatif berwarna merah. ${ }^{22}$ Bakteri memiliki beberapa bentuk yaitu bacillus (batang), coccus (bulat), dan spirilum (lengkung). Bakteri yang berbentuk bacillus dibagi atas diplobacillus dan tripobacillus. Pada bentuk coccus dibagi atas monococcus, diplococcus, sampai staphylococcus (bentuknya mirip buah anggur). Khusus pada spirilum hanya dibagi dua yaitu setengah melengkung dan tidak melengkung. ${ }^{22,23}$

Dalam penelitian ini hanya digunakan metode pewarnaan Gram untuk identifikasi bakteri dengan kelebihan dan kekurangannya. Kelebihannya ialah pewarnaan Gram merupakan salah satu metode paling sederhana dan murah untuk diagnosis cepat infeksi bakteri. Metode ini jauh lebih cepat dibandingkan dengan kultur bakteri, dan sebagai pedoman awal untuk memutuskan terapi antibiotik sebelum tersedia bukti definitif bakteri penyebab infeksi secara spesifik. Kekurangan dari metode ini yaitu hanya dapat mengetahui ukuran dan bentuk bakteri serta melihat struktur dalam bakteri dengan zat warna saja. Kondisi pewarnaan Gram dan morfologi bakteri kadangkadang berubah karena terapi antimikroba. Spesies batang Gram negatif dapat menjadi filamen dan pleomorfik sedangkan bakteri 
Gram positif dapat menjadi bervariasi setelah terapi antimikroba. ${ }^{24}$

\section{SARAN}

Disarankan penelitian lebih lanjut dengan uji biokimia pada koloni yang timbul untuk diferensiasi koloni bakteri yaitu uji motilitas, uji produksi $\mathrm{H}_{2} \mathrm{~S}$, dan uji pertumbuhan sitrat agar dapat mengetahui jenis bakteri Gram positif dan Gram negatif secara spesifik.

\section{SIMPULAN}

Berdasarkan hasil penelitian ini dapat disimpulkan bahwa bakteri Gram positif berbentuk coccus yang paling sering menjadi penyebab infeksi mata luar.

\section{DAFTAR PUSTAKA}

1. Ongko E. Perancangan sistem pakar diagnosa penyakit pada mata. Jurnal Times. 2013;II(2):10-7.

2. Eguchi H, Hotta F, Kuwahara T, Imaohji $\mathrm{H}$, Miyazaki $\mathrm{C}$, Hirose $\mathrm{M}$, et al. Diagnostic approach to ocular infections using various techniques from conventional culture to next-generation sequencing analysis. Cornea. 2017; 36:S46-52.

3. Lynn WA, Lightman S. The eye in systemic infection. Lancet. 2004;364(9443): 1439-50.

4. Sherwal BL, Verma AK. Epidemiology of ocular infection due to bacteria and fungus-a prospective study. JK science. 2008;10(3):127-31.

5. Bertino Jr JS. Impact of antibiotic resistance in the management of ocular infections: the role of current and future antibiotics. Clinical Ophthalmology (Auckland, NZ). 2009;3:507.

6. Sharma S. Antibiotic resistance in ocular bacterial pathogens. Indian Journal of Medical Microbiology. 2011;29(3):218.

7. De Campos AM, Sánchez A, Alonso MJ. Chitosan nanoparticles: a new vehicle for the improvement of the delivery of drugs to the ocular surface. Application to cyclosporin A. Int J Pharm. 2001; 224(1-2):159-68.

8. Galvis V, Tello A, Guerra A, Acuña MF, Villarreal D. Antibiotic susceptibility patterns of bacteria isolated from keratitis and intraocular infections at
Fundación Oftalmológica de Santander (FOSCAL), Floridablanca, Colombia. Biomedica. 2014;34:23-33.

9. Iwalokun BA, Oluwadun A, Akinsinde KA, Niemogha MT, Nwaokorie FO. Bacteriologic and plasmid analysis of etiologic agents of conjunctivitis in Lagos, Nigeria. J Ophthalmic Inflamm Infect. 2011;1(3):95-103.

10. World Health Organization. Blindness and vision impairment, October 2018. [cited 2018 Dec 18]. Available from: https://www.who.int/news-room/ fact-sheets/detail/blindness-and visualimpairment

11. Badan Litbang Kementerian Kesehatan. Riset Kesehatan Dasar Tahun 2013. [cited 2018 Nov 27]. Available from:http://www.depkes.go.id/folder/vi ew/01/structure-publikasipus datininfo-datin.html

12. Balai Kesehatan Mata Masyarakat Kota Manado. Data 10 Penyakit Terbanyak Tahun 2017

13. Wang N, Yang Q, Tan Y, Lin L, Huang Q, Wu K. Bacterial spectrum and antibiotic resistance patterns of ocular infection: differences between external and intraocular diseases. J Ophthalmol. 2016;9(3): 384-9.

14. Shiferaw B, Gelaw B, Assefa A, Assefa Y, Addis Z. Bacterial isolates and their antimicrobial susceptibility pattern among patients with external ocular infections at Borumeda hospital, Northeast Ethiopia. BMC ophthalmol. 2015;15(1):103.

15. Rajesh S, Divya B, Aruna V. Microbiological profile of external ocular infections in a Tertiary Care Hospital in South India. Int J Curr Microbiol App Sci. 2017;6(7):4343-52.

16. Teweldemedhin M, Gebreyesus $H$, Atsbaha AH, Asgedom SW, Saravanan M. Bacterial profile of ocular infections: a systematic review. BMC Ophthalmol. 2017;17(1);212,

17. Szczotka-Flynn LB, Pearlman E, Ghannoum M. Microbial contamination of contact lenses, lens care solutions, and their accessories: A literature review. Eye Contact Lens. 2010;36(2):116-29.

18. Tesfaye T, Beyene G, Gelaw Y, Bekele S, Saravanan M. Bacterial profile and 
antimicrobial susceptibility pattern of external ocular infections in Jimma University Specialized Hospital, Southwest Ethiopia. Am J Infect Dis Microbiol. 2013;17:151.

19. Amsalu A, Abebe T, Mihret A, Delelegne D, Tadesse E. Potential bacterial pathogens of external ocular infections and their antibiotic susceptibility pattern at Hawassa University teaching and referral Hospital, Southern Ethiopia. Afr J Microbiol Res. 2015; 9(14):1012-9.

20. Ubani UA. Bacteriology of external ocular infections in Aba, South Eastern Nigeria. Clin Exp Optom. 2009;
92(6):482-9.

21. Schaumberg DA, Dana R, Buring JE, Sullivan DA. Prevalence of dry eye disease among US men: Estimates from the physicians' health studies. Arch Ophthalmol. 2009;127(6):763-8.

22. Waluyo L. Teknik dan Metode Dasar dalam Mikrobiologi. Malang: Universitas Muhammadiyah Malang Press, 2008.

23. Usman W. Buku Ajar Mikrobiologi Kedokteran (Edisi Revisi). Jakarta: Binarupa Aksara, 2010; p.125-50.

24. Nagata K, Mino H, Yoshida S. Usefulness and limit of Gram staining smear examination. Rinsho Byori. 2010; 58(5):490-7. 